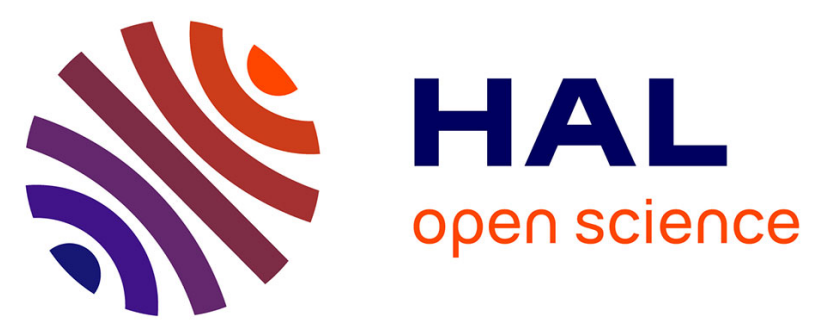

\title{
Metabolic and histochemical characteristics of fat and muscle tissues in homozygous or heterozygous pigs for the body composition QTL located on chromosome 7
}

Julie Demars, Juliette Riquet, Marie-Pierre Sanchez, Yvon Y. Billon, Jean-François J.-F. Hocquette, Bénédicte Lebret, Nathalie N. Iannuccelli, Jean Pierre Bidanel, Denis Milan, Florence Gondret

\section{To cite this version:}

Julie Demars, Juliette Riquet, Marie-Pierre Sanchez, Yvon Y. Billon, Jean-François J.-F. Hocquette, et al.. Metabolic and histochemical characteristics of fat and muscle tissues in homozygous or heterozygous pigs for the body composition QTL located on chromosome 7. Physiological Genomics, 2007, 30 (3), pp.232-241. 10.1152/physiolgenomics.00270.2006 . hal-02662501

\section{HAL Id: hal-02662501 https://hal.inrae.fr/hal-02662501}

Submitted on 31 May 2020

HAL is a multi-disciplinary open access archive for the deposit and dissemination of scientific research documents, whether they are published or not. The documents may come from teaching and research institutions in France or abroad, or from public or private research centers.
L'archive ouverte pluridisciplinaire HAL, est destinée au dépôt et à la diffusion de documents scientifiques de niveau recherche, publiés ou non, émanant des établissements d'enseignement et de recherche français ou étrangers, des laboratoires publics ou privés. 
Julie Demars, Juliette Riquet, Marie-Pierre Sanchez, Yvon Billon, Jean-François

Hocquette, Bénédicte Lebret, Nathalie Iannuccelli, Jean-Pierre Bidanel, Denis

Milan and Florence Gondret

Physiol Genomics 30:232-241, 2007. First published Apr 10, 2007;

doi:10.1152/physiolgenomics.00270.2006

You might find this additional information useful...

This article cites 42 articles, 19 of which you can access free at:

http://physiolgenomics.physiology.org/cgi/content/full/30/3/232\#BIBL

Updated information and services including high-resolution figures, can be found at:

http://physiolgenomics.physiology.org/cgi/content/full/30/3/232

Additional material and information about Physiological Genomics can be found at:

http://www.the-aps.org/publications/pg

This information is current as of September 9, 2010 .

Physiological Genomics publishes results of a wide variety of studies from human and from informative model systems with techniques linking genes and pathways to physiology, from prokaryotes to eukaryotes. It is published quarterly in January, April, July, and October by the American Physiological Society, 9650 Rockville Pike, Bethesda MD 20814-3991. Copyright () 2007 by the American Physiological Society. ISSN: 1094-8341, ESSN: 1531-2267. Visit our website at http://www.the-aps.org/. 


\title{
Metabolic and histochemical characteristics of fat and muscle tissues in homozygous or heterozygous pigs for the body composition QTL located
}

\section{on chromosome 7}

\author{
Julie Demars, ${ }^{1}$ Juliette Riquet, ${ }^{1}$ Marie-Pierre Sanchez, ${ }^{2}$ Yvon Billon, ${ }^{3}$ Jean-François Hocquette, ${ }^{4}$ \\ Bénédicte Lebret, ${ }^{5}$ Nathalie Iannuccelli, ${ }^{1}$ Jean-Pierre Bidanel, ${ }^{2}$ Denis Milan, ${ }^{1}$ and Florence Gondret ${ }^{5}$ \\ ${ }^{1}$ Institut National de la Recherche Agronomique (INRA), Unité Mixte de Recherche (UMR)444, Laboratoire de Génétique \\ Cellulaire, BP52627, Castanet-Tolosan; ${ }^{2} I N R A$, Unité de Recherche (UR)337, Station de Génétique Quantitative et Appliquée, \\ Jouy en Josas; ${ }^{3} I N R A$, Unité d'Enseignement (UE)967, Domaine expérimental du Magneraud, Surgères; ${ }^{4} I N R A$, UR1213, \\ Unité de Recherches sur les Herbivores, Saint Genès Champanelle; and ${ }^{5}$ INRA, UMR1079, Systèmes d'Elevage Nutrition \\ Animale et Humaine, Saint-Gilles, France
}

Submitted 8 December 2006; accepted in final form 5 April 2007

\begin{abstract}
Demars J, Riquet J, Sanchez M-P, Billon Y, Hocquette J-F, Lebret B, Iannuccelli N, Bidanel J-P, Milan D, Gondret F. Metabolic and histochemical characteristics of fat and muscle tissues in homozygous or heterozygous pigs for the body composition QTL located on chromosome 7. Physiol Genomics 30: 232-241, 2007. First published April 10, 2007; doi:10.1152/physiolgenomics.00270.2006.-Quantitative trait loci (QTL) influencing many traits including backfat thickness and carcass composition have been detected on porcine chromosome 7 (SSC7) in an F2 cross between Large White (LW) and Meishan (MS) pigs. However, the genes and controlled pathways underlying the QTL effects on body phenotype remain unknown. This study aimed at investigating the tissue characteristics at metabolic and cellular levels in pigs that were either homozygous or heterozygous for a body composition SSC7 QTL. A backcross pig (BC3) was first progeny tested to confirm its heterozygoty for the SSC7 QTL; results on all offspring $(n=80)$ confirmed the QTL effects on body fatness. This boar was then mated with three sows known to be heterozygous for this QTL. In the subset of pigs per genotype, we found that heterozygous $\mathrm{LW}_{\mathrm{QTL} 7} / \mathrm{MS}_{\mathrm{QTL}}$ pigs had smaller adipocytes in backfat, together with a lower basal rate of glucose incorporation into lipids and lower activities of selected lipogenic enzymes in backfat isolated cells, compared with homozygous $\mathrm{LW}_{\mathrm{QTL} 7} / \mathrm{LW}_{\mathrm{QTL} 7}$ pigs. A higher number of adipocytes was also estimated in backfat of $\mathrm{LW}_{\mathrm{QTL} 7} /$ $\mathrm{MS}_{\mathrm{QTL} 7}$ animals compared with $\mathrm{LW}_{\mathrm{QTL} 7} / \mathrm{LW}_{\mathrm{QTL}}$ pigs. The SSC7 QTL did not influence oxidative and glycolytic metabolisms of longissimus and trapezius muscles, as estimated by the activities of specific energy metabolism enzymes, or the myofiber type properties. Altogether, this study provides new evidence for an altered adipocyte cellularity in backfat of pigs carrying at least one MS allele for the SSC7 QTL. Some candidate genes known for their functions on adipocyte growth and differentiation are suggested.
\end{abstract}

quantitative trait locus; porcine chromosome 7; energy metabolism; lipogenesis; adipocytes

THE IDENTIFICATION OF GENES underlying body composition is of major interest for the improvement of livestock animal production and for a better knowledge of mammalian physiology, including the human obesity-related phenotype. One strategy to achieve that is to identify porcine genomic regions containing quantitative trait loci (QTL) for economically important

Article published online before print. See web site for date of publication (http://physiolgenomics.physiology.org).

Address for reprint requests and other correspondence: F. Gondret, INRA, UMR1079, Systèmes d'Elevage Nutrition Animale et Humaine, F-35590 Saint-Gilles, France (e-mail: Florence.Gondret@rennes.inra.fr). traits, such as carcass composition. In pigs, a QTL with marked effects on body fatness has been detected on chromosome 7 (SSC7), using an F2 cross between European Large White (LW) and Chinese Meishan (MS) divergent founder breeds (4, 30, 33, 39). Pure MS pig populations deposit more fat than conventional Western breeds of pigs (34). However, alleles originating from the MS breed in the SSC7 QTL region, which are partially dominant over the LW alleles (33), are surprisingly associated with a lower fat percentage and a higher lean meat content of the carcass in all studies $(11,40)$.

In early life, adipose tissue expansion results from the development of adipocytes originating from precursor cells (adipogenesis), under the influence of numerous transcription factors (6). Then, the deposition of fat into differentiated adipose cells mainly results from the balance of absorption of fatty acids circulating in blood, de novo lipogenesis, esterification, lipolysis, and in situ lipid oxidation. Previous studies have shown that pig breeds with a greater propensity to fatten have larger adipocytes and consequently fewer cells per gram of adipose tissue than lean pigs $(20,41)$. Both elevated lipogenic enzyme activities and in vitro lipogenic rate have also been associated with the variation of adiposity between fat and lean pig breeds $(20,31,41)$. Since skeletal muscle is the primary site of insulin-stimulated glucose disposal and whole body lipid oxidation, close relationships between the potential of muscle to use carbohydrates or lipid fuels and the development or maintenance of body fat mass have also been described recently in various species. In particular, reduced activity levels of the oxidative enzymes citrate synthase (CS), $\beta$-hydroxyacyl-CoA dehydrogenase (HAD), and/or cytochrome- $c$ oxidase (COX) and elevated phosphofructokinase (PFK) activity as an index of the glycolytic capacity have been found in skeletal muscle of obese humans $(23,42)$. However, compared with lean LW pigs, the MS pigs exhibit a more oxidative and a less glycolytic muscle metabolism, as well as a higher capacity to use lipids as an energetic substrate (27).

Conservation of the syntenies between porcine SSC7 and human chromosomes 6, 14, and 15 has been demonstrated (44), although some microrearrangements occur in the swine QTL region $(9,10)$. About 120 genes are localized in the SSC7 interval $(9.7 \mathrm{cM})$ close to the swine leukocyte antigen complex between SW1856 and NFY microsatellites markers (11). Some of these genes have known or suggested biological roles in adipose cell growth and differentiation, storage of fatty acids, 


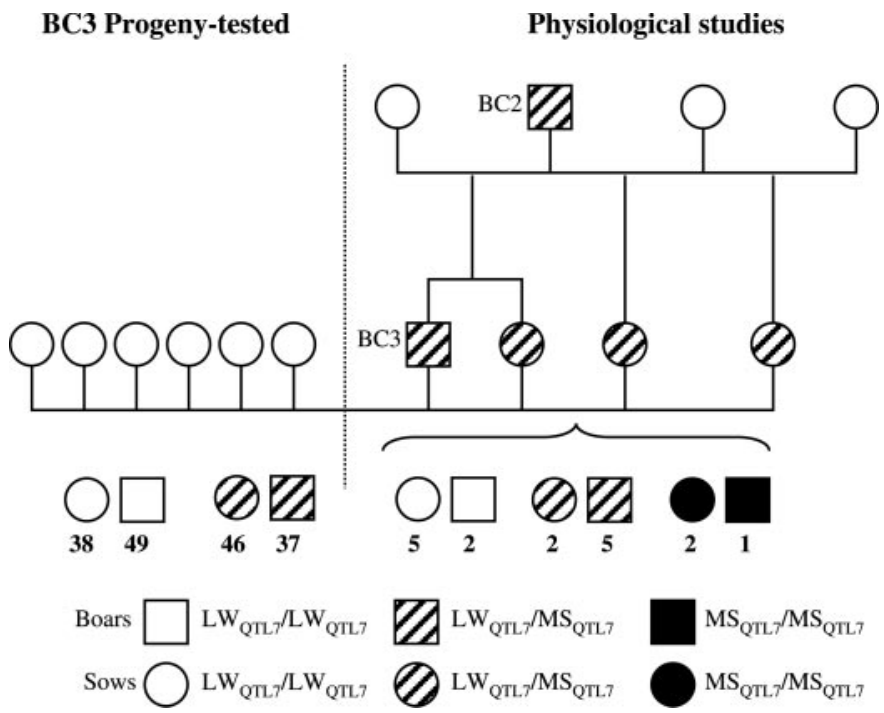

Fig. 1. Pedigrees of animals used for metabolic and physiological studies of the porcine chromosome 7 (SSC7) quantitative trait locus (QTL). $\mathrm{LW}_{\mathrm{QTL} 7} /$ $\mathrm{LW}_{\mathrm{QTL} 7}, \mathrm{LW}_{\mathrm{QTL}} / \mathrm{MS}_{\mathrm{QTL}}$, and $\mathrm{MS}_{\mathrm{QTL}} / \mathrm{MS}_{\mathrm{QTL}}$ : animals that are homozygous Large White LW/LW, homozygous Meishan MS/MS, and heterozygous LW/MS in the mapping interval of the SSC7 body composition QTL, respectively, and have a 15/16 similar LW genetic background. The boar that was progeny tested belonged to a third-generation backcross (BC3) and was shown to be heterozygous for the SSC7 QTL (experiment 1). This boar was mated to 3 sows with a $\mathrm{LW}_{\mathrm{QTL}} / \mathrm{MS}_{\mathrm{QTL}}$ genotype (experiment 2 ) to produce the 3 possible QTL genotypes ( $\mathrm{LW}_{\mathrm{QTL} 7} / \mathrm{LW}_{\mathrm{QTL} 7}, \mathrm{LW}_{\mathrm{QTL}} / \mathrm{MS}_{\mathrm{QTL}}$, and $\mathrm{MS}_{\mathrm{QTL}} /$ $\left.\mathrm{MS}_{\mathrm{QTL7}}\right)$.

downstream events implicated in the adipogenic action of insulin, oxidation, or muscle contractile apparatus. The present study aimed to investigate the main cellular and metabolic pathways related to lipid accumulation or energy expenditure in adipose tissue and skeletal muscles of pigs with either the LW/LW or LW/MS genotype for the SSC7 QTL but having the same genetic background. This may give some indication of the candidate genes at the SSC7 QTL responsible for the genetic effects on body fatness variation in pigs.

\section{MATERIALS AND METHODS}

\section{Genetic Analyses}

Experimental animals. Animals were reared and slaughtered in accordance with French standard guidelines for human care and use of animals in research (certificate of authorization to experiment on living animal no. 35-22 delivered by the French Department of Agriculture to F. Gondret).

A recombinant backcross design was developed for the fine mapping of a carcass composition QTL located on chromosome 7 as described in Demeure et al. (11). Offspring originating from a secondgeneration backcross (BC2) boar found to be heterozygous at the QTL through progeny testing were produced, among which one male (BC3) and three females were kept for breeding. These four animals all presented an identical-by-descent MS segment inherited from a single female MS ancestor. Their pedigree is presented in Fig. 1. They were used to produce two different experimental crosses.

Experiment 1. The BC3 boar was mated to $14 \mathrm{LW}$ sows and was subsequently progeny tested to identify its genotype for the SSC7 QTL. Offspring $(n=80)$ were performance tested and slaughtered in a commercial slaughterhouse (Fleury-les-Aubrais, France) at $\sim 150$ days of age. Several traits related to carcass composition were assessed, as explained in RESULTS.

Experiment 2. To produce pigs with the same genetic background and differing only for the SSC7 QTL region, the BC3 boar was mated to its three heterozygous LW/MS half-sister sows. BC3 was then the father of all pigs used for metabolic and cellular studies. Three different genotypes were thus obtained: homozygous LW/LW $\left(\mathrm{LW}_{\mathrm{QTL} 7} / \mathrm{LW}_{\mathrm{QTL} 7}\right)$, homozygous $\mathrm{MS} / \mathrm{MS}\left(\mathrm{MS}_{\mathrm{QTL} 7} / \mathrm{MS}_{\mathrm{QTL}}\right)$, and heterozygous LW/MS ( $\mathrm{LW}_{\mathrm{QTL} 7} / \mathrm{MS}_{\mathrm{QTL}}$ ) in the SSC7 QTL region. All of these animals have a 15/16 similar LW genetic background. Pigs were fed ad libitum with conventional diets for weaning, postweaning, and growing-finishing periods. At $\sim 150$ days of age, seven $\mathrm{LW}_{\mathrm{QTL} 7} / \mathrm{LW}_{\mathrm{QTL} 7}\left(n=5\right.$ females, and $n=2$ barrows), three $\mathrm{MS}_{\mathrm{QTL} 7} /$ $\mathrm{MS}_{\mathrm{QTL7}}\left(n=2\right.$ females, and $n=1$ barrow), and seven LW $\mathrm{LWTL}_{\mathrm{QT}} /$ $\mathrm{MS}_{\mathrm{QTL7}}$ ( $n=2$ females, and $n=5$ barrows) pigs were weighed individually and transferred to the INRA experimental slaughterhouse of Saint-Gilles, France (transport duration, 3 h). They were slaughtered after overnight fasting by electrical stunning and exsanguination in compliance with present national regulations applied in slaughterhouses. Body composition, tissue sampling, and physiological characteristics of selected tissues were then assessed as explained below.

\section{Molecular Analyses}

All offspring resulting from the progeny test (experiment 1) and their parents and grandparents were typed for seven microsatellites markers covering the SSC7 QTL region (from 4 to $105 \mathrm{cM}$ ). The names and locations of microsatellites markers are indicated in Fig. 2. DNA was extracted from tail samples. Amplifications were performed on ABI 9700 PCR machines (Applied Biosystems, Foster City, CA), and genotyping was carried out on an ABI 3730 automatic sequencer (Applied Biosystems). Genotypes were then determined using the

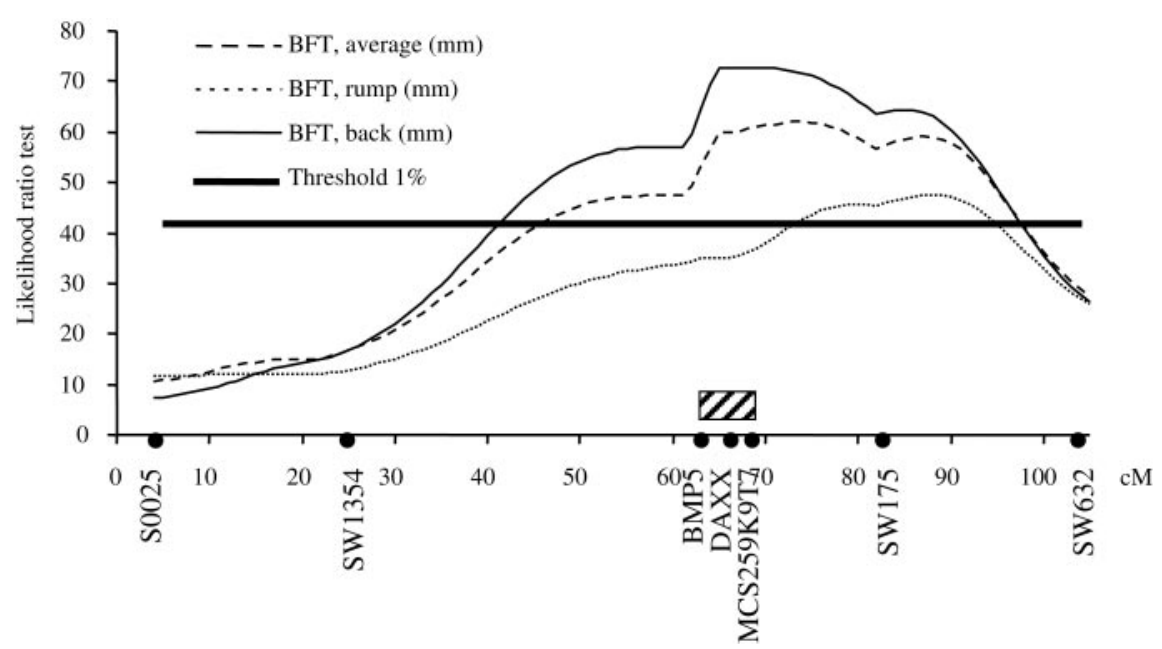

Fig. 2. Likelihood ratio curves on swine chromosome 7 for single-trait, single-QTL mapping. Results are of QTL analysis for backfat thickness (BFT) measured after slaughter. The different markers used and their locations are represented by black circles. The box represents the interval of localization of the QTL. 
Genescan and Genotyper softwares (Applied Biosystems). Results of genotyping were checked, validated, and stored in the GEMMA database (21).

\section{Carcass Measurements}

Carcass weight and length were recorded shortly after slaughter. Perirenal fat (leaf fat) was weighed at the same moment. Subcutaneous fat thickness (backfat thickness; BFT) was measured using a Fat-O-Meater probe (SFK, Herlev, Denmark) at the levels of the back [means of measurements taken at the 3rd/4th lumbar vertebra (G1) and 3rd/4th last rib (G2) levels], the neck (means of 2 measures), and/or the rump (means of 2 measures). Muscle depth was measured at the 3rd/4th last rib levels (loin eye depth, M2). Lean meat content (LMC) was estimated using an equation combining G1, G2, and M2 measurements (8).

The carcass was then chilled at $4^{\circ} \mathrm{C}$ for one night. The day after, the right half-carcass was divided into retail cuts (ham, loin, belly, shoulder, backfat) that were individually weighed. Chilled perirenal fat and the entire longissimus and trapezius muscles excised from the loin and shoulder cuts, respectively, were individually weighed.

\section{Tissue Sampling}

For adipocyte isolation purposes, fresh portions of subcutaneous backfat (at the 5th lumbar vertebra level) were excised from the left carcass side, just after pig exsanguination. Minced tissues were placed in warm Krebs-Ringer bicarbonate buffer (Sigma, St. Quentin Fallavier, France) and immediately processed. For histological, biochemical, and enzyme analyses, samples of backfat (last rib level) and longissimus (last rib level, i.e., a white fast-twitch glycolytic muscle) and trapezius (middle portion, a red slow-twitch oxidative muscle) muscles were excised from the left carcass side within 30 min after exsanguination. Visible intermuscular adipose tissue was carefully removed from muscles. Then, backfat adipose tissue and skeletal muscles oriented following the myofiber longitudinal axis were put on flat sticks, frozen in liquid nitrogen, and stored at $-75^{\circ} \mathrm{C}$ until analyses.

\section{Isolation of Adipocytes}

Adipocytes were collected after a collagenase (Roche Applied Science, Meylan, France; $0.22 \mathrm{U} / \mathrm{mg}$ ) treatment of backfat, as described previously (13) but with some adaptations (29). Briefly, samples of minced backfat were shaken $(40 \mathrm{rpm})$ for $60 \mathrm{~min}$ at $37^{\circ} \mathrm{C}$ in sterile polypropylene flasks in Krebs-Ringer bicarbonate buffer ( 3 $\mathrm{ml} / \mathrm{g}$ tissue) containing 3\% bovine serum albumin (BSA), $10 \mathrm{mM}$ glucose, $1.3 \mathrm{mg} / \mathrm{ml}$ collagenase $\mathrm{A}$, and antibiotics. The digested material was then filtered through $200-\mu \mathrm{m}$ sterile nylon mesh filters. Adipocytes were allowed to float; they were then rinsed three times with DMEM (5.5 mM glucose; Invitrogen, Cergy-Pontoise, France) by removing the infranatant using a plastic catheter attached to a syringe. Cells were then maintained in the same medium at $37^{\circ} \mathrm{C}$ in an atmosphere of $\mathrm{O}_{2}-\mathrm{CO}_{2}(95: 5 \%)$. An aliquot $\left(10^{3}\right.$ cells $)$ of isolated adipocytes was placed on a heated $\left(37^{\circ} \mathrm{C}\right)$ glass plate and immediately digitized using a photomicroscopy system. Individual diameters were measured using an image analysis system (Optimas 6.5; Media $\mathrm{Cy}$ bernetics, Silver Spring, MD). Cell diameters were categorized into classes (every $10 \mu \mathrm{m}$ ), and the relative frequency of adipocytes in each class was then calculated. Because of problems during the isolation procedure, only four $\mathrm{LW}_{\mathrm{QTL} 7} / \mathrm{MS}_{\mathrm{QTL}}$ pigs and four $\mathrm{LW}_{\mathrm{QTL} 7} / \mathrm{LW}_{\mathrm{QTL} 7}$ pigs could be finally considered.

\section{Glucose Incorporation into Lipids}

The lipogenic rate was estimated by quantifying the conversion of D-[U- $\left.{ }^{14} \mathrm{C}\right]$ glucose (GE Healthcare, Orsay, France) into lipids on day 1 after cell isolation, as previously described (15). Briefly, cells $(\sim 2 \times$ $10^{5}$ cells) were incubated with $0.4 \mu \mathrm{Ci}$ of $\mathrm{D}-\left[\mathrm{U}-{ }^{14} \mathrm{C}\right]$ glucose at $37^{\circ} \mathrm{C}$, either in the absence (basal rate) or in the presence of insulin (17 nM) under an $\mathrm{O}_{2}-\mathrm{CO}_{2}(95: 5 \%)$ atmosphere. After $4 \mathrm{~h}$ of incubation, the medium was removed. Dole's reagent was immediately added, and lipids were extracted (12). Incorporated radioactivity was measured by liquid scintillation counting. The number of adipocytes in the suspension was determined as previously described (29) from the measurement of lipid content in the aliquot of suspension (12), and the mean adipocyte volume was determined as described above, under the assumption that the cells were spherical. Glucose incorporation into lipids was expressed as nanomoles of glucose incorporated per $10^{7}$ cells per $4 \mathrm{~h}$.

\section{Tissue Lipid Content}

Lipid content in backfat and muscles was estimated using the total lipid extraction procedure outlined by Folch and et al. (14) and was expressed as percentage per gram of fresh tissue. Total amounts of lipids in tissue cuts were calculated considering chilled weights of tissues of the right carcass side.

\section{Histochemistry}

For adipocyte measurements, three cross sections of frozen backfat (10- $\mu \mathrm{m}$ thick, 50- $\mu \mathrm{m}$ intervals) were obtained from each sample, using a cryostat at $-30^{\circ} \mathrm{C}$. Tissue sections were fixed for $10 \mathrm{~min}$ in $0.1 \mathrm{M}$ phosphate buffer containing $2.5 \%$ ( $\mathrm{vol} / \mathrm{vol})$ glutaraldehyde ( $25 \%$ aqueous solution; Sigma, St. Louis, MO). They were stained for $4 \mathrm{~min}$ in isopropanol containing $0.5 \%$ oil red $\mathrm{O}$ (wt/vol), and membranes of adipocytes and myofibers were then counterstained in an aqueous solution of crystal violet indicator (17). Visible adipocytes in three randomly chosen fields per section were carefully reproduced on transparent plastic sheets using a projection microscope (Visopan, Reichert, Vienna), and individual cell areas were measured using a programmable planimeter (Hitachi Siko, Tokyo, Japan). Mean diameter $(\mu \mathrm{m})$ of adipocytes was then calculated. The number of adipocytes per gram of backfat was estimated by dividing the total lipid content expressed per gram of backfat by the adipocyte mean volume (26), considering that triglyceride density is $\sim 0.96$.

For myofiber histochemistry, five serial transverse cross sections $\left(10-\mu \mathrm{m}\right.$ thick) were cut in each muscle using the cryostat at $-20^{\circ} \mathrm{C}$. One section was stained in red with azorubin for reference. Crosssectional areas of the myofibers $\left(\mathrm{CSA}, \mu \mathrm{m}^{2}\right)$ were measured using a macro-program developed on the Optimas image analysis system, on three randomly digitized fields. Three other sections were processed for actomyosin ATPase activity after acidic preincubation at $\mathrm{pH} 4.25$, 4.35 , and 4.45 (7) to identify slow-twitch type I, fast-twitch type IIA, and fast-twitch type IIB/X fibers. The last section was stained for succinate dehydrogenase ( $\mathrm{SDH})$ activity (37) to assess the aerobic oxidative capacity of the fibers. Relative percentages of type I, IIA, or IIB/X or SDH-positive myofibers of each muscle sample were determined on the basis of three selected fields of 300 fibers each per sample, using the projection microscope.

\section{Lipogenic Enzyme Activities}

A weighed quantity of backfat (about $0.6 \mathrm{~g}$ ) was homogenized in 2 $\mathrm{ml}$ of ice-cold $0.25 \mathrm{M}$ sucrose containing $1 \mathrm{mM}$ dithiothreitol and 1 mM EDTA. The mixture was then centrifuged at $100,000 \mathrm{~g}$ for $1 \mathrm{~h}$ at $4^{\circ} \mathrm{C}$, and the cytosolic fraction was collected and stored at $-75^{\circ} \mathrm{C}$. Activities of enzymes representing a key step in the formation of palmitic acid (fatty acid synthase; FAS) or providing a reduced equivalent for fatty acid synthesis (malic enzyme; ME) were measured according to the method described by Bazin and Ferré (3). Enzyme activities were assayed spectrophotometrically at 340-nm absorbance following the disappearance (FAS) or the production (ME) of NADPH. Substrate quantities were optimized $(50-300 \mu l)$ to ensure linearity of the reactions. Lipogenic enzyme activities were expressed as nanomoles of NADPH per minute and per gram of tissue. 
Enzyme data were also expressed in units per cell, by dividing the activity per gram of tissue by the number of adipocytes per gram of backfat as calculated above. Finally, protein content of the cytosolic fraction was determined using the bicinchoninic acid assay with BSA as standard. Enzyme activities were then also expressed as nanomoles of NADPH per minute and per milligram of proteins.

\section{Catabolic Energy Enzyme Activities}

A frozen portion of muscles $(\sim 0.2 \mathrm{~g})$ was homogenized in $50 \mathrm{vol}$ (wt/vol) of ice-chilled $0.1 \mathrm{M}$ phosphate buffer ( $\mathrm{pH} 7.5$ ) containing 2 $\mathrm{mM}$ EDTA and sonicated. After centrifugation at $1,700 \mathrm{~g}$ for $15 \mathrm{~min}$ at $4{ }^{\circ} \mathrm{C}$, the supernatant fraction (soluble enzymes and mitochondrial material) was collected and used for further analyses. The maximal activities of mitochondria oxidative markers, reflecting either fatty acid $\beta$-oxidation (HAD), mitochondrial density (CS), and/or phosphorylative oxidation (COX), were determined spectrophotometrically according to methods described previously $(2,43)$. In addition, the activities of PFK and of lactate dehydrogenase (LDH) as markers of anaerobic glycolysis were determined in the same samples (46). Enzyme activities were expressed as micromoles of substrate degraded per minute and per gram of fresh muscle. Total enzyme activities in the muscles were calculated by multiplying the activities per gram of muscle by the weights of individual muscles. Protein content of the total fraction was determined as described above. Enzyme activities were also expressed as nanomoles per minute and per milligram of proteins.

\section{Statistical Analyses}

Statistical analysis software (SAS; SAS Institute, Cary, NC) was used for data analyses.

In experiment 1 , progeny test analyses were conducted similarly to those described by Sanchez et al. (40). Data were first adjusted for environmental effects using the GLM procedure of SAS (1999) and corrected for the fixed effects of batch and sex. Some traits were additionally adjusted to a constant weight by adding slaughter weight as a covariate in the model. A half/full-sibling model was used, which assumes that the sire progeny is distributed into several independent full-sibling families. For each centimorgan along a chromosome, the hypothesis of one QTL (H1) linked to the set of markers considered was compared with the hypothesis of no QTL (H0) at the same location. Under the H1 hypothesis, a single-QTL model with a gene substitution effect for the sire and for each dam was fitted to the data. Likelihoods were then maximized under each hypothesis, and the statistical test was computed as the ratio of likelihoods ( $\mathrm{L}$ ratio). Average substitution effects were estimated for the sire and each dam family at the location with the highest $\mathrm{L}$ ratio (28). Significance thresholds were determined, assuming a polygenic infinitesimal model and a normal distribution of phenotypes (28).

In experiment 2, final live weight measurements were compared using a fixed linear model with the QTL genotype and sex as main effects. The same model, including pig weight assessed just before transportation as a covariate, was used for data analysis of carcass traits and metabolic and cellular characteristics of backfat and skeletal muscles. The effect of interaction between QTL genotype and sex was tested in preliminary analyses but never reached significance $(P>$ $0.10)$; consequently, it was removed from the final model. The analyses were performed using the GLM procedure of SAS software (SAS Institute, 1999). Least square mean values for QTL genotype were compared using the PDIFF statement of the GLM procedure. Differences were considered to be significant at $P \leq 0.10$.

\section{RESULTS}

\section{Experiment 1: Genetic Analyses}

Results of QTL effects on body composition traits in the backcross family are presented in Table 1. Significant effects
Table 1. Carcass composition traits affected by swine chromosome 7 QTL segregation in the backcross Large White family

\begin{tabular}{lcccc}
\hline \hline \multicolumn{1}{c}{ Traits } & No. of Animals & $P$ Value & Position, cM & Estimated Effect \\
\hline BFT, average (mm) & 79 & $\dagger$ & 74 & 2.728 \\
BFT, rump (mm) & 79 & $\dagger$ & 88 & 2.673 \\
BFT, back (mm) & 80 & $\dagger$ & 69 & 3.764 \\
BFT, neck (mm) & 80 & NS & 67 & 1.662 \\
LMC (\%) & 80 & $\S$ & 65 & -0.754 \\
G1 (mm) & 80 & $*$ & 74 & 1.662 \\
G2 (mm) & 80 & $\dagger$ & 65 & 1.783 \\
M2 (mm) & 80 & NS & 41 & 2.797 \\
Carcass length (mm) & 80 & $\dagger$ & 67 & -22.114 \\
Ham (kg) & 80 & $\dagger$ & 29 & 0.132 \\
Belly (kg) & 80 & $*$ & 65 & 0.134 \\
Backfat (kg) & 80 & $\dagger$ & 65 & 0.189 \\
Loin (kg) & 80 & NS & 24 & 0.139 \\
\hline
\end{tabular}

QTL, quantitative trait locus; NS, not significant; BFT, backfat thickness; LMC, lean mean content; G1 and G2, fat measurements at the levels of 3rd to 4th lumbar vertebrae $(\mathrm{G} 1)$ and 3rd to 4th last ribs $(\mathrm{G} 2)$; M2, lean depth of longissimus at 3 rd to 4 th last ribs level. $P$ values: $0.05(\ddagger)$ and $0.01(\S)$ chromosome-wide significance levels and $0.10(*)$ and $0.05(\dagger)$ experimentwide significance levels. "Estimated effect" is the estimate of the allele substitution effect (Large White-Meishan alleles) in trait units.

were obtained in the region of the SSC7 QTL for most carcass composition traits, especially backfat traits (weight and thickness at G1 and G2 levels, $P<0.1$ ), estimated LMC $(P=0.01)$, and belly weight $(P<0.1)$. Likelihood ratio curves are presented in Fig. 2 for BFT. It clearly shows that the BC3 progeny tested boar, which had a LW/MS haplotype between BMP5 and MCS259K9T7 microsatellites markers, was heterozygous for the QTL of interest in the SSC7 region.

\section{Experiment 2: Physiological Phenotyping}

Only results obtained for homozygous $\mathrm{LW}_{\mathrm{QTL} 7} / \mathrm{LW}_{\mathrm{QTL} 7}$ and heterozygous $\mathrm{LW}_{\mathrm{QTL} 7} / \mathrm{MS}_{\mathrm{QTL} 7}$ pigs are presented. The number of homozygous $\mathrm{MS}_{\mathrm{QTL}} / \mathrm{MS}_{\mathrm{QTL} 7}$ animals still alive at final age (only 3 pigs) was too low to estimate genotypic means with a sufficient accuracy. Moreover, principal component analysis further showed that two of these pigs markedly deviated for all measurements performed (data not shown).

Pigs were the same age at the time of slaughter, and final live weight and hot and cold carcass weights did not significantly differ between homozygous $\mathrm{LW}_{\mathrm{QTL} 7} / \mathrm{LW}_{\mathrm{QTL} 7}$ and heterozygous $\mathrm{LW}_{\mathrm{QTL} 7} / \mathrm{MS}_{\mathrm{QTL}}$ pigs (Table 2 ). Whatever their genotype at the SSC7 QTL, females were lighter $(P=0.01)$ than barrows at slaughter. The $\mathrm{LW}_{\mathrm{QTL} 7} / \mathrm{LW}_{\mathrm{QTL} 7}$ pigs exhibited higher perirenal fat weight $(P<0.05)$ and elevated proportions of belly $(+18 \%)$ and fatty cuts $(+17 \%$ for the sum of backfat and belly) in the carcass than $\mathrm{LW}_{\mathrm{QTL} 7} / \mathrm{MS}_{\mathrm{QTL}}$ pigs. Although backfat thickness was $3.8 \mathrm{~mm}$ higher at the $\mathrm{G} 1$ level $(P=0.07)$ for $\mathrm{LW}_{\mathrm{QTL} 7} / \mathrm{LW}_{\mathrm{QTL} 7}$ than $\mathrm{LW}_{\mathrm{QTL}} / \mathrm{MS}_{\mathrm{QTL}}$ pigs (Table 2), no haplotype-related differences were observed for backfat weight (data not shown) and the relative proportion of backfat in the carcass. Relative proportions of loin, ham, and shoulder and of the sum of lean cuts (loin + ham + shoulder) in the carcass were not significantly different between genotypes, although they were close to significance $(P=0.11)$ for the proportion of ham. There were no sex-related differences in carcass compo- 
Table 2. Body weight and composition at slaughter for $L W_{Q T L 7} / L W_{Q T L 7}$ and $L W_{Q T L} / M S_{Q T L 7}$ pigs

\begin{tabular}{|c|c|c|c|c|c|}
\hline \multirow[b]{2}{*}{ Traits } & \multirow[b]{2}{*}{$\mathrm{LW}_{\mathrm{QTL} 7 / \mathrm{LW}}$} & \multirow[b]{2}{*}{$\mathrm{LW}_{\mathrm{QTL} 7 / \mathrm{MS}_{\mathrm{QTL} 7}}$} & \multirow[b]{2}{*}{ SE } & \multicolumn{2}{|c|}{$P$ Value } \\
\hline & & & & Genotype & Sex \\
\hline Live weight, $\mathrm{kg}$ & 89.0 & 95.3 & 9.3 & 0.28 & 0.01 \\
\hline Hot carcass weight, kg & 69.8 & 70.6 & 0.9 & 0.18 & 0.84 \\
\hline Cold carcass weight, $\mathrm{kg}$ & 68.0 & 68.7 & 0.9 & 0.23 & 0.86 \\
\hline Perirenal fat, $g$ & 1,130 & 566 & 261 & 0.006 & 0.21 \\
\hline \multicolumn{6}{|c|}{ Backfat thickness, mm } \\
\hline G1 & 18.1 & 14.3 & 3.0 & 0.07 & 0.5 \\
\hline $\mathrm{G} 2$ & 14.8 & 12.3 & 3.4 & 0.23 & 0.1 \\
\hline Average & 16.4 & 13.3 & 3.0 & 0.13 & 0.23 \\
\hline \multicolumn{6}{|c|}{ Carcass composition, \%* } \\
\hline Backfat & 7.0 & 5.9 & 2.0 & 0.38 & 0.37 \\
\hline Belly & 13.7 & 11.6 & 0.8 & 0.002 & 0.97 \\
\hline Fatty retail cuts $\dagger$ & 19.4 & 16.5 & 2.1 & 0.05 & 0.39 \\
\hline Loin & 27.6 & 27.1 & 1.5 & 0.58 & 0.11 \\
\hline Ham & 23.6 & 24.9 & 1.2 & 0.11 & 0.71 \\
\hline Shoulder & 25.5 & 26.2 & 0.7 & 0.17 & 0.04 \\
\hline Lean retail cuts $\ddagger$ & 76.7 & 78.2 & 1.9 & 0.24 & 0.51 \\
\hline
\end{tabular}

Homozygous $\mathrm{LW}_{\mathrm{QTL}} / \mathrm{LW}_{\mathrm{QTL} 7}(n=7)$ or heterozygous $\mathrm{LW}_{\mathrm{QTL} 7} / \mathrm{MS}_{\mathrm{QTL}}(n=7)$ pigs for porcine chromosome 7 (SSC7) QTL. LW, Large White; MS, Meishan. *Weight percentage of the carcass. $†$ Sum of backfat and belly weights. $\ddagger$ Sum of loin, ham, and shoulder weights. $P$ values are levels of significance for the effect of the genotype group and sex.

sition, except a slightly lower proportion of shoulder in females than in barrows.

\section{Lipid-Related Traits}

The relative content and the total amount of lipids in backfat and in muscles did not differ between $\mathrm{LW}_{\mathrm{QTL}} / \mathrm{LW}_{\mathrm{QTL}}$ pigs and $\mathrm{LW}_{\mathrm{QTL} 7} / \mathrm{MS}_{\mathrm{QTL}}$ pigs (Table 3). Mean diameter of backfat adipocytes estimated from tissue slices was $18 \%$ smaller in $\mathrm{LW}_{\mathrm{QTL} 7} / \mathrm{MS}_{\mathrm{QTL} 7}$ pigs than in $\mathrm{LW}_{\mathrm{QTL} 7} / \mathrm{LW}_{\mathrm{QTL}}$ animals; consequently, adipocytes in backfat were calculated to be far numerous in $\mathrm{LW}_{\mathrm{QTL}} / \mathrm{MS}_{\mathrm{QTL}}$ than $\mathrm{LW}_{\mathrm{QTL}} / \mathrm{LW}_{\mathrm{QTL}}$ pigs (Table 3). Results from adipocyte isolation confirmed the reduction in cell diameter for $\mathrm{LW}_{\mathrm{QTL}} / \mathrm{MS}_{\mathrm{QTL}}$ compared with $\mathrm{LW}_{\mathrm{QTL}} / \mathrm{LW}_{\mathrm{QTL}}$ pigs $(-13 \%, P=0.05$, data not shown). The diagrams of the distribution of cell diameters show that differences between genotypes are in particular related to a lower proportion of large adipocytes (diameter $>60 \mu \mathrm{m}$ ) in $\mathrm{LW}_{\mathrm{QTL} 7} /$ $\mathrm{MS}_{\mathrm{QTL} 7}$ compared with $\mathrm{LW}_{\mathrm{QTL}} / \mathrm{LW}_{\mathrm{QTL}}$ pigs. However, the sharp cut-off in the distribution pattern at the lower ends also suggests that cells exhibiting a diameter lower than $20 \mu \mathrm{m}$ could not really be considered in our experimental conditions. Therefore, a difference in the proportion of small adipocytes $(<20 \mu \mathrm{m})$ between genotypes could not be excluded.

The basal rate of glucose incorporation into lipids was markedly lower in backfat cells of $\mathrm{LW}_{\mathrm{QTL}} / \mathrm{MS}_{\mathrm{QTL}}$ pigs than in those of $\mathrm{LW}_{\mathrm{QTL}} / \mathrm{LW} \mathrm{W}_{\mathrm{QTL}}$ pigs (Table 3). In both genotypes, insulin addition in the medium resulted in a dramatic increase in the lipogenic rate. However, differences in insulinstimulated rate of lipogenesis between genotypes did not reach statistical significance $(P=0.18)$.

Activities of FAS and ME as selected enzymes involved in lipogenesis were twofold lower in $\mathrm{LW}_{\mathrm{QTL}} / \mathrm{MS}_{\mathrm{QTL}}$ pigs than in $\mathrm{LW}_{\mathrm{QTL}} / \mathrm{LW}_{\mathrm{QTL} 7}$ animals when expressed per adipose cells. When expressed per gram of wet tissue or per milligram of proteins, the data of enzyme activities did not differ between both genotypes.

\section{Cellular and Metabolic Muscle Characteristics}

The weights of longissimus (1,937 and 1,767 $\mathrm{g}$ in $\mathrm{LW}_{\mathrm{QTL} 7} /$ $\mathrm{LW}_{\mathrm{QTL}}$ and $\mathrm{LW}_{\mathrm{QTL}} / \mathrm{MS}_{\mathrm{QTL} 7}$ pigs, respectively) and trapezius (97 and $91 \mathrm{~g}$ in $\mathrm{LW}_{\mathrm{QTL} 7} / \mathrm{LW}_{\mathrm{QTL} 7}$ and $\mathrm{LW}_{\mathrm{QTL}} / \mathrm{MS}_{\mathrm{QTL}}$ pigs, respectively) muscles did not differ between the two genotypes. In addition, there was no difference in the mean cross-sectional areas of the myofibers between genotypes for both muscles (Tables 4 and 5). No significant genotype-related differences were observed for the activities of the oxidative enzymes or glycolytic enzymes in both longissimus (Table 4) and trapezius (Table 5) muscles when expressed per gram of tissue, per milligram of proteins, or per wet tissue. The ratio of LDH (glycolysis) to CS (oxidation) activities tended to be higher in the longissimus of $\mathrm{LW}_{\mathrm{QTL}} / \mathrm{MS}_{\mathrm{QTL}}$ pigs compared with $\mathrm{LW}_{\mathrm{QTL}} / \mathrm{LW}_{\mathrm{QTL}}$ pigs $(270$ vs. $226, P=0.10)$ but did not differ between genotypes in the trapezius (data not shown). Finally, in both muscles, the proportions of fiber types were similar between $\mathrm{LW}_{\mathrm{QTL} 7} / \mathrm{LW}_{\mathrm{QTL}}$ pigs and $\mathrm{LW}_{\mathrm{QTL}} / \mathrm{MS}_{\mathrm{QTL}}$ pigs (Tables 4 and 5).

\section{DISCUSSION}

The effects of the SSC7 QTL on carcass measurements have been largely documented in the literature $(4,30,33,39)$. However, the present approach is the first one aiming to characterize at a tissue level the metabolic and cellular effects of the genotype at SSC7 QTL. To analyze these aspects, pigs with a similar 15/16 Large White genetic background and either homozygous LW/LW or MS/MS or heterozygous LW/MS for SSC7 QTL were produced. Only results of $\mathrm{LW}_{\mathrm{QTL} 7} / \mathrm{LW}_{\mathrm{QTL} 7}$ and $\mathrm{LW}_{\mathrm{QTL}} / \mathrm{MS}_{\mathrm{QTL}}$ were presented because the strength of $\mathrm{MS}_{\mathrm{QTL} 7} / \mathrm{MS}_{\mathrm{QTL}}$ was too small, and pigs were very heterogeneous. Progeny testing of the $\mathrm{BC} 3$ boar used as a sire allowed us to confirm the QTL effects on carcass traits previously described in the second-generation backcross pigs of the INRA PorQTL program $(11,40)$. Indeed, a decreased fat thickness at the back and rump levels and a lower 
Table 3. Lipid-related traits at slaughter in backfat and muscles from $L W_{Q T L 7} / L W_{Q T L 7}$ and $L W_{Q T L 7} / M S_{Q T L 7}$ pigs

\begin{tabular}{|c|c|c|c|c|c|}
\hline \multirow[b]{2}{*}{ Variables } & \multirow[b]{2}{*}{$\mathrm{LW}_{\mathrm{QTL} 7} / \mathrm{LW}_{\mathrm{QTL} 7}$} & \multirow[b]{2}{*}{$\mathrm{LW}_{\mathrm{QTL} 7} / \mathrm{MS}_{\mathrm{QTL} 7}$} & \multirow[b]{2}{*}{ SE } & \multicolumn{2}{|c|}{$P$ Value } \\
\hline & & & & Genotype & Sex \\
\hline \multicolumn{6}{|c|}{ Backfat } \\
\hline Lipid content, g per $100 \mathrm{~g}$ wet tissue & 54.1 & 54.3 & 0.07 & 0.97 & 0.34 \\
\hline Total amount of lipids in tissue, $\mathrm{g}^{*}$ & 1,239 & 1,125 & 451 & 0.70 & 0.52 \\
\hline Adipocyte diameter, $\mu \mathrm{m}$ & 61.4 & 50.0 & 6.0 & 0.01 & 0.20 \\
\hline Adipocyte no., per g of tissue $\left(\times 10^{9}\right)$ & 5.1 & 8.8 & 2.1 & 0.02 & 0.11 \\
\hline Total no. of adipocytes in tissue $\left(\times 10^{12}\right)$ & 10.9 & 15.8 & 3.7 & 0.06 & 0.62 \\
\hline \multicolumn{6}{|c|}{ Glucose incorporation into lipids, nmol/4 h and per $10^{7} \mathrm{cells} \dagger$} \\
\hline Basal rate & 2.0 & 1.1 & 0.6 & 0.01 & 0.77 \\
\hline With insulin $(17 \mathrm{nM})$ & 6.3 & 5.0 & 4.0 & 0.19 & 0.85 \\
\hline \multicolumn{6}{|c|}{ Lipogenic enzymes activities, nmol/min and per $10^{7}$ cells $\$$} \\
\hline FAS & 0.6 & 0.3 & 0.2 & 0.03 & 0.40 \\
\hline ME & 7.4 & 3.9 & 2.0 & 0.02 & 0.24 \\
\hline \multicolumn{6}{|c|}{ Lipogenic enzymes activities, nmol/min and per g tissue } \\
\hline FAS & 276 & 299 & 156 & 0.81 & 0.48 \\
\hline ME & 3,301 & 3,510 & 858 & 0.70 & 0.50 \\
\hline \multicolumn{6}{|c|}{ Lipogenic enzymes activities, nmol/min and per mg proteins $\ddagger$} \\
\hline FAS & 42.7 & 37.0 & 20.7 & 0.67 & 0.77 \\
\hline ME & 509 & 468 & 169 & 0.70 & 0.96 \\
\hline \multicolumn{6}{|c|}{ Longissimus muscle } \\
\hline Lipid content, g per $100 \mathrm{~g}$ wet tissue & 1.3 & 1.4 & 0.01 & 0.76 & 0.18 \\
\hline Total amount of lipids in tissue, $\mathrm{g}$ & 24.5 & 24.4 & 6.6 & 0.98 & 0.27 \\
\hline \multicolumn{6}{|c|}{ Trapezius muscle } \\
\hline Lipid content, g per $100 \mathrm{~g}$ fresh tissue & 5.4 & 5.0 & 0.02 & 0.78 & 0.23 \\
\hline Total amount of lipids in tissue, $\mathrm{g}$ & 5.4 & 4.8 & 2.4 & 0.70 & 0.28 \\
\hline
\end{tabular}

Homozygous $\mathrm{LW}_{\mathrm{QTL} 7} / \mathrm{LW}_{\mathrm{QTL} 7}(n=7)$ or heterozygous $\mathrm{LW}_{\mathrm{QTL}} / \mathrm{MSS}_{\mathrm{QTL} 7}(n=7)$ pigs for SSC7 QTL. *Total amount of lipids in the cut obtained in the right carcass. $†$ Capacity of $\left[{ }^{14} \mathrm{C}\right]$ glucose incorporation in backfat adipose tissue was determined in the absence (basal rate) or presence $(17 \mathrm{nM})$ of insulin $(n=4$ in each group). $¥$ Activities of malic enzyme (ME) and fatty acid synthase (FAS) were expressed as nanomoles of NADH produced or catabolized per minute. $P$ values are levels of significance for the effects of genotype group and sex.

backfat weight (experiment 1,80 descendants), together with a lower perirenal fat weight and a lower proportion of fatty cuts in the carcass (experiment 2, 14 descendants), were shown in pigs carrying at least one MS allele at the SSC7 QTL level. Although backfat thickness at the G1 level tended to be lower in $\mathrm{LW}_{\mathrm{QTL} 7} / \mathrm{MS}_{\mathrm{QTL} 7}$ pigs compared with homozygous $\mathrm{LW}_{\mathrm{QTL}} / \mathrm{LW} \mathrm{WTL}_{\mathrm{QT}}$ pigs, no significant $\mathrm{QTL}$ effects were observed on mean backfat thickness and backfat weight in experiment 2. Since SSC7 QTL explains $\sim 12-14 \%$ of the phenotypic variance in carcass fatness traits on F2 animals (33), the lack of significant differences in backfat weight $(-16 \%)$ between $\mathrm{LW}_{\mathrm{QTL} 7} / \mathrm{MS}_{\mathrm{QTL}}$ pigs and $\mathrm{LW}_{\mathrm{QTL}} / \mathrm{LW}_{\mathrm{QTL} 7}$ pigs is likely to be due to the low number of animals in the experimental design and the heterogeneity of body weight at slaughter. When a limited number of pigs is considered, present results suggest that perirenal fat weight (leaf fat) would be the best indicator of the SSC7 QTL genotype status of tested boars.

Since backfat represents the main site of lipid storage in pigs, the cellular and metabolic characteristics of backfat were investigated in the present study. Despite the lack of any significant difference on quantitative backfat traits, present results provide new evidence for a lower diameter of adipocytes in heterozygous $\mathrm{LW}_{\mathrm{QTL}} / \mathrm{MS}_{\mathrm{QTL}}$ pigs compared with homozygous $\mathrm{LW}_{\mathrm{QTL} 7} / \mathrm{LW}_{\mathrm{QTL} 7}$ pigs. Additionally, $\mathrm{MS}_{\mathrm{QTL} 7} /$ $\mathrm{MS}_{\mathrm{QTL} 7}$ pigs exhibited numerically smaller $(-25 \%)$ adipocytes in backfat than $\mathrm{LW}_{\mathrm{QTL}} / \mathrm{MS}_{\mathrm{QTL}}$ animals (data not shown); this contrast was similar to that observed between
$\mathrm{LW}_{\mathrm{QTL} 7} / \mathrm{MS}_{\mathrm{QTL}}$ and $\mathrm{LW}_{\mathrm{QTL}} / \mathrm{LW}_{\mathrm{QTL} 7}$ pigs. These results strongly suggest that the difference in backfat adipocyte diameter between genotypes might be associated with the presence of the MS allele at the SSC7 QTL. This is somewhat surprising, since pure MS breed pigs display enlarged adipocytes in backfat compared with pure LW breed pigs when slaughtered at the same live weight (5). Nevertheless, this observation seems in accordance with the effect of the SSC7 QTL; the MS allele is associated with a lower fat percentage $(4,33)$. Adipocyte volume is largely dependent on the accumulation of triacylglycerols, and de novo lipogenesis in the tissue is one possible mechanism resulting in accumulation of triacylglycerols (45), especially in pigs fed a high-starch diet (20). In accordance, we reported a lower basal ability to convert glucose into lipids in isolated adipocytes from $\mathrm{LW}_{\mathrm{QTL}} / \mathrm{MS}_{\mathrm{QTL}}$ than from $\mathrm{LW}_{\mathrm{QTL}} / \mathrm{LW}_{\mathrm{QTL}}$ pigs, together with depressed lipogenic enzyme activities per backfat cell in pigs carrying at least one MS allele. The choice of unit for enzyme activity expression is very important in the interpretation of data from adipose tissue containing cells of varying size. The cellular basis has been shown to be the preferred method of expression (20). When expressed on a wet tissue basis or on a soluble protein basis, no differences were observed between genotypes for enzyme data, since the reference units failed to take into account adipose cell size (20). Altogether, our results are in close connection with other experiments indicating that differences in adiposity between pig breeds are mainly related to differences in the lipogenic rate and enzyme activities per cells 
Table 4. Catabolic energy metabolism and myofiber type composition in longissimus muscle from $L W_{Q T L 7} / L W_{Q T L 7}$ and $L W_{Q T L 7} / M S_{Q T L 7}$ pigs

\begin{tabular}{|c|c|c|c|c|c|}
\hline \multirow[b]{2}{*}{ Variables } & \multirow[b]{2}{*}{$\mathrm{LW}_{\mathrm{QTL} 7 / \mathrm{LW}_{\mathrm{QTL} 7}}$} & \multirow[b]{2}{*}{$\mathrm{LW}_{\mathrm{QTL} 7} / \mathrm{MS}_{\mathrm{QTL} 7}$} & \multirow[b]{2}{*}{ SE } & \multicolumn{2}{|c|}{$P$ Value } \\
\hline & & & & Genotype & Sex \\
\hline \multicolumn{6}{|c|}{ Enzyme activities, $\mu \mathrm{mol} / \mathrm{min}$ and per $\mathrm{g}$ tissue* } \\
\hline HAD & 4.2 & 3.5 & 0.7 & 0.18 & 0.52 \\
\hline $\mathrm{CS}$ & 5.7 & 4.9 & 1.1 & 0.25 & 0.39 \\
\hline $\operatorname{COX}$ & 6.1 & 6.3 & 2.2 & 0.86 & 0.38 \\
\hline PFK & 28.6 & 36.1 & 20.0 & 0.56 & 0.65 \\
\hline LDH & 1,877 & 1,897 & 267 & 0.90 & 0.13 \\
\hline \multicolumn{6}{|c|}{ Enzyme activities, $n$ mol/min and per $m g$ proteins* } \\
\hline HAD & 20.0 & 16.3 & 3.5 & 0.13 & 0.92 \\
\hline $\mathrm{CS}$ & 28.8 & 26.4 & 4.6 & 0.44 & 0.11 \\
\hline $\mathrm{COX}$ & 30.6 & 33.9 & 10.1 & 0.61 & 0.18 \\
\hline PFK & 148 & 198 & 128 & 0.54 & 0.86 \\
\hline LDH & 6,453 & 6,886 & 535 & 0.22 & 0.43 \\
\hline \multicolumn{6}{|c|}{ Total enzyme activities, $\mathrm{mmol} / \mathrm{min}$ in wet muscle* } \\
\hline HAD & 8.1 & 6.3 & 1.6 & 0.11 & 0.97 \\
\hline CS & 11.0 & 8.7 & 2.5 & 0.15 & 0.88 \\
\hline $\operatorname{COX}$ & 11.8 & 11.4 & 4.9 & 0.90 & 0.68 \\
\hline PFK & 55.2 & 65.4 & 44.7 & 0.72 & 0.59 \\
\hline LDH & 364 & 338 & 69 & 0.56 & 0.65 \\
\hline \multicolumn{6}{|c|}{ Myofiber properties } \\
\hline Mean cross-sectional area, $\mu \mathrm{m}^{2}$ & 6,701 & 7,124 & 1,421 & 0.64 & 0.83 \\
\hline \multicolumn{6}{|c|}{ Type percentage, \% } \\
\hline I & 10.1 & 10.1 & 4.7 & 0.99 & 0.79 \\
\hline IIA & 9.0 & 6.5 & 2.7 & 0.16 & 0.40 \\
\hline IIB/X & 80.9 & 83.4 & 4.3 & 0.36 & 0.81 \\
\hline SDH positive $\dagger$ & 28.4 & 25.8 & 3.8 & 0.30 & 0.28 \\
\hline
\end{tabular}

Homozygous $\mathrm{LW}_{\mathrm{QTL} 7} / \mathrm{LW}_{\mathrm{QTL} 7}(n=7)$ or heterozygous $\mathrm{LW}_{\mathrm{QTL}} / \mathrm{MSS}_{\mathrm{QTL} 7}(n=7)$ pigs for the SSC7 QTL. *Activities of lactate dehydrogenase $(\mathrm{LDH})$, citrate synthase (CS), and beta-hydroxy-acyl-CoA-dehydrogenase (HAD) were expressed as micromoles per minutes per gram of fresh muscle; cytochrome $C$ oxidase (COX) was expressed as units per gram of tissue wet weight. $†$ Succinate dehydrogenase (SDH) activity. PFK, phosphofructokinase. $P$ values are levels of significance for the effects of genotype group and sex.

$(20,41)$. However, none of the lipogenic enzymes investigated here could be retained as a candidate for the SSC7 QTL effects, since ME and FAS loci are mapped on SSC1 (38) and SSC12 (35), respectively. Furthermore, insulin addition stimulated in vitro glucose conversion into lipids in a similar manner for both genotypes under experiment. This might be an argument to exclude genes coding for downstream events implicated in the lipogenic action of insulin from the SSC7 QTL effects.

Interestingly, FAS and ME enzymes have also been described as late markers of differentiation during the adipogenic process (6). Then, the lower lipogenic activities in adipocytes from $\mathrm{LW}_{\mathrm{QTL} 7} / \mathrm{MS}_{\mathrm{QTL}}$ pigs compared with $\mathrm{LW}_{\mathrm{QTL}} / \mathrm{LW}_{\mathrm{QTL} 7}$ pigs might be a consequence rather than a cause of the smaller adipocyte diameter of the heterozygous pigs at the QTL. This might indicate a lower physiological maturity of adipose cells of $\mathrm{LW}_{\mathrm{QTL}} / \mathrm{MS}_{\mathrm{QTL}}$ pigs compared with $\mathrm{LW}_{\mathrm{QTL}} / \mathrm{LW}_{\mathrm{QTL}}$ pigs when compared at the same age. In accordance, a delayed maturity of adipose tissue has been suggested in the pure MS breed compared with the lean Pietrain breed during animal growth (19). Because backfat lipid content was similar in both genotype groups, it can be concluded that the MS allele at SSC7 QTL was associated with an increased number of adipocytes, on a wet tissue weight basis as per backfat depot. Again, $\mathrm{MS}_{\mathrm{QTL}} / \mathrm{MS}_{\mathrm{QTL}}$ pigs also displayed more numerous adipocytes $(+44 \%)$ than $\mathrm{LW}_{\mathrm{QTL}} / \mathrm{MS}_{\mathrm{QTL} 7}$ animals (data not shown). It is clear that the procedure for estimating cell numbers may also underestimate the true value, because it does not really account for cells $<20 \mu \mathrm{m}$ in diameter. However, a higher rate of proliferation of preadipocytes in MS animals compared with pure LW animals has been demonstrated previously in primary cultures (16). This feature closely agrees with present results indicating a higher adipocyte number in backfat of pigs carrying at least one MS allele. Altogether, the higher number and lower diameter of adipocytes associated with the lower basal ability to convert glucose into lipids in backfat cells of $\mathrm{LW}_{\mathrm{QTL} 7} / \mathrm{MS}_{\mathrm{QTL} 7}$ pigs compared with $\mathrm{LW}_{\mathrm{QTL} 7} /$ $\mathrm{LW}_{\mathrm{QTL}}$ pigs indicate that further work could focus on SSC7 genes with known or suggested functions in the extent and kinetics of adipogenesis. In accordance, a slow differentiation or a later commitment of precursors to adipocyte differentiation has been suggested previously in an MS pure population compared with a Western pig breed (19).

Interestingly, this porcine SSC7 QTL region $(9,10)$ contains genes with critical roles in adipose cell growth and differentiation, such as mitogen-activated protein kinase [MAPK14/p38 (1)], high-motility group AT-hook 1 [HMGA1 (32)], and peroxisome proliferator-activated receptor- $\delta$ (18). In particular, HMGA1 polymorphism was previously found to be associated with fat deposition in European commercial lines $(24,25)$. Another gene of importance for the adipogenic process in the SSC7 QTL interval might be the cyclin-dependent kinase inhibitor (CDKN1A) known to regulate adipocyte number in mammals (36). The precise functions of one or a cascade of these SSC7 QTL genes in the regulation of adipogenesis and 
Table 5. Catabolic energy metabolism and myofiber type composition in trapezius muscle from $L W_{Q T L} / L W_{Q T L 7}$ and $L W_{Q T L 7} / M S_{Q T L 7}$ pigs

\begin{tabular}{|c|c|c|c|c|c|}
\hline \multirow[b]{2}{*}{ Variables } & \multirow[b]{2}{*}{$\mathrm{LW}_{\mathrm{QTL} 7} / \mathrm{LW}_{\mathrm{QTL} 7}$} & \multirow[b]{2}{*}{$\mathrm{LW}_{\mathrm{QTL} 7} / \mathrm{MS}_{\mathrm{QTL} 7}$} & \multirow[b]{2}{*}{ SE } & \multicolumn{2}{|c|}{$P$ Value } \\
\hline & & & & Genotype & Sex \\
\hline \multicolumn{6}{|c|}{ Enzyme activities, $\mu \mathrm{mol} / \mathrm{min}$ and per $\mathrm{g}$ tissue* } \\
\hline HAD & 12.4 & 11.7 & 1.4 & 0.42 & 0.38 \\
\hline $\mathrm{CS}$ & 18.1 & 16.9 & 2.1 & 0.40 & 0.86 \\
\hline COX & 22.6 & 23.5 & 6.4 & 0.83 & 0.46 \\
\hline PFK & 15.3 & 21.6 & 6.6 & 0.16 & 0.54 \\
\hline LDH & 609 & 502 & 130 & 0.22 & 0.73 \\
\hline \multicolumn{6}{|c|}{ Enzyme activities, $\mathrm{nmol} / \mathrm{min}$ and per $\mathrm{mg}$ proteins* } \\
\hline HAD & 494 & 457 & 84 & 0.49 & 0.60 \\
\hline CS & 721 & 658 & 114 & 0.28 & 0.40 \\
\hline $\operatorname{COX}$ & 144 & 147 & 41 & 0.89 & 0.51 \\
\hline PFK & 98 & 134 & 39 & 0.18 & 0.56 \\
\hline LDH & 23.9 & 19.2 & 4.4 & 0.12 & 0.39 \\
\hline \multicolumn{6}{|c|}{ Enzyme activities, $\mathrm{mmol} / \mathrm{min}$ in wet muscle* } \\
\hline HAD & 1.2 & 1.1 & 0.3 & 0.35 & 0.40 \\
\hline CS & 1.8 & 1.5 & 0.4 & 0.34 & 0.53 \\
\hline COX & 2.2 & 2.2 & 0.8 & 0.96 & 0.48 \\
\hline PFK & 1.5 & 1.9 & 0.7 & 0.29 & 0.82 \\
\hline LDH & 58.6 & 45.4 & 16.4 & 0.22 & 0.53 \\
\hline \multicolumn{6}{|c|}{ Myofibers properties } \\
\hline Mean cross-sectional area, $\mu \mathrm{m}^{2}$ & 3,802 & 4,145 & 423 & 0.22 & 0.01 \\
\hline \multicolumn{6}{|c|}{ Type percentage, $\%$} \\
\hline I & 45 & 43 & 5 & 0.49 & 0.40 \\
\hline IIA & 21 & 22 & 3 & 0.86 & 0.76 \\
\hline IIB/X & 34 & 36 & 4 & 0.54 & 0.25 \\
\hline
\end{tabular}

Homozygous $\mathrm{LW}_{\mathrm{QTL} 7} / \mathrm{LW}_{\mathrm{QTL} 7}(n=7)$ or heterozygous $\mathrm{LW}_{\mathrm{QTL}} / \mathrm{MS}_{\mathrm{QTL}}(n=7)$ pigs for the SSC7 QTL. *Activities of HAD, CS, COX, PFK, and LDH. $P$ values are levels of significance for the effects of genotype group and sex.

more generally their effects on the characteristics of porcine adipose cells deserve further study.

The second major finding of this study is that muscle characteristics are rather similar in carriers and noncarriers of the MS allele. By contrast, significant differences in myofiber size and muscle oxidative metabolism have been found between MS and LW breeds (27). In the present study, skeletal muscles of $\mathrm{LW}_{\mathrm{QTL}} / \mathrm{MS}_{\mathrm{QTL}}$ and $\mathrm{LW}_{\mathrm{QTL}} / \mathrm{LW}_{\mathrm{QTL}}$ pigs had the same weights and similar myofiber mean cross-sectional areas and type distribution. In addition, activities of citrate synthase and cytochrome- $c$ oxidase enzymes, which are considered convenient and fairly reliable markers of mitochondrial content and function, respectively (22), did not markedly differ between pig carriers or noncarriers of the MS allele at the SSC7 QTL. Only the metabolic differentiation of muscle, defined as the glycolytic-to-oxidative enzyme activity ratio, tended to be higher in the longissimus muscle of $\mathrm{LW}_{\mathrm{QTL}} /$ $\mathrm{MS}_{\mathrm{QTL}}$ pigs compared with $\mathrm{LW}_{\mathrm{QTL}} / \mathrm{LW}_{\mathrm{QTL}}$ pigs. Several genes related to the cytochrome $c$ (CYCSL 1 for cytochrome $c$ somatic-like 1, LOC285849 for similar to cytochrome-c oxidase subunit VIa polypeptide 1 precursor, COX6A1P2 for cytochrome- $c$ oxidase subunit VIa polypeptide 1 pseudogene 2) or muscle contractile apparatus (LOC442204 for similar to myosin subunit regulatory light chain) are present in the mapping interval of the SSC7 body composition QTL $(9,10)$. Contrary to studies in humans showing reduced oxidative enzyme activities in skeletal muscle of obese individuals (e.g., Refs. 23, 42), present results demonstrate that skeletal muscles are not the target organs of the SSC7 QTL genes. The present results do not support the association of positional candidate genes related to substrate oxidation with SSC7 QTL effects on pig body composition.

In conclusion, the limited number of progeny used in this experiment was large enough to detect the very strong effects of the SSC7 QTL chromosomal region on adipocyte cellularity and metabolism. One aim of this study was to identify a fine phenotypic measure for use in future progeny tests, eventually resulting in the production of fewer animals to determine homozygoty or heterozygoty at the SSC7 QTL. Significant results obtained on adipocyte cellularity suggest that this measure could be used. Additional progeny testing is necessary to evaluate its efficacy as a fine phenotypic measurement. This phenotypic study using the pig QTL region provides new information on the biological basis of fat mass variation. Results indicate that further studies aiming to understand SSC7 QTL effects may focus on a few candidate genes involved in the adipogenic process rather than genes involved in catabolic oxidative pathways. Additional studies of polymorphisms for these candidate genes in various pig breeds chosen for their divergence in body composition phenotypes, together with siRNA analyses of these few candidate genes using porcine preadipocytes in culture, are now required.

\section{ACKNOWLEDGMENTS}

We are very grateful to F. Pontrucher, N. Bonhomme, C. Tréfeu, P. Ecolan, M. Bonnet, D Chadeyron (INRA, Theix, France), the staff of the slaughterhouse, and the team of the INRA experimental farm of le Magneraud for expert technical assistance. Excellent scientific advice from I. Louveau and L. Lefaucheur is also acknowledged. Genotyping was performed on the Centre de 
Ressources-Génotypage et Séquençage (CRGS) platform of Toulouse Midi Pyrénées Genopole.

\section{GRANTS}

J. Demars is supported by a $\mathrm{PhD}$ grant from the Fonds Social Européen.

\section{REFERENCES}

1. Aouadi M, Laurent K, Prot M, Le Marchand-Brustel Y, Binetruy B, Bost F. Inhibition of p38MAPK increases adipogenesis from embryonic to adult stages. Diabetes 55: 281-289, 2006.

2. Bass A, Brdiczka D, Eyer P, Hofer S, Pette D. Metabolic differentiation of distinct muscle types at the level of enzymatic organization. Eur J Biochem 10: 198-206, 1969.

3. Bazin R, Ferré P. Assays of lipogenic enzymes. Methods Mol Biol 155: 121-127, 2001.

4. Bidanel JP, Milan D, Iannuccelli N, Amigues Y, Boscher MY, Bourgeois F, Caritez JC, Gruand J, Le Roy P, Lagant H, Quintanilla R, Renard C, Gellin J, Ollivier L, Chevalet C. Detection of quantitative trait loci for growth and fatness in pigs. Genet Sel Evol 33: 289-309, 2001.

5. Bonneau M, Mourot J, Noblet J, Lefaucheur L, Bidanel J. Tissue development in Meishan pigs: muscle and fat development and metabolism and growth regulation by somatotropic hormone. Chinese Pig Symposium: 203-213, 1990.

6. Boone C, Mourot J, Gregoire F, Remacle C. The adipose conversion process: regulation by extracellular and intracellular factors. Reprod Nutr Dev 40: 325-358, 2000.

7. Brooke MH, Kaiser KK. Three "myosin adenosine triphosphatase" systems: the nature of their $\mathrm{pH}$ lability and sulfhydryl dependence. J Histochem Cytochem 18: 670-672, 1970.

8. Daumas G, Dhorne T. Teneur en viande maigre des carcasses de porc. Evaluation et estimation. Journées Recherche Porcine 29: 411-418, 1997.

9. Demars J, Riquet J, Feve K, Gautier M, Morisson M, Demeure O, Renard C, Chardon P, Milan D. High resolution physical map of porcine chromosome 7 QTL region and comparative mapping of this region among vertebrate genomes. BMC Genomics 7: 13, 2006.

10. Demeure O, Renard C, Yerle M, Faraut T, Riquet J, Robic A, Schiex T, Rink A, Milan D. Rearranged gene order between pig and human in a QTL region on SSC 7. Mamm Genome 14: 71-80, 2003.

11. Demeure O, Sanchez MP, Riquet J, Iannuccelli N, Demars J, Feve K, Kernaleguen L, Gogue J, Billon Y, Caritez JC, Milan D, Bidanel JP. Exclusion of the swine leukocyte antigens as candidate region and reduction of the position interval for the Sus scrofa chromosome 7 QTL affecting growth and fatness. J Anim Sci 83: 1979-1987, 2005.

12. Dole VP, Meinertz H. Microdetermination of long-chain fatty acids in plasma and tissues. J Biol Chem 235: 2595-2599, 1960.

13. Etherton TD, Chung CS. Preparation, characterization, and insulin sensitivity of isolated swine adipocytes: comparison with adipose tissue slices. J Lipid Res 22: 1053-1059, 1981.

14. Folch J, Lees M, Sloane Stanley GH. A simple method for the isolation and purification of total lipides from animal tissues. J Biol Chem 226: 497-509, 1957.

15. Foster CM, Hale PM, Jing HW, Schwartz J. Effects of human growth hormone on insulin-stimulated glucose metabolism in 3T3-F442A adipocytes. Endocrinology 123: 1082-1088, 1988.

16. Gerfault V, Louveau I, Mourot J. The effect of GH and IGF-I on preadipocytes from Large White and Meishan pigs in primary culture. Gen Comp Endocrinol 114: 396-404, 1999.

17. Gondret F, Lebret B. Feeding intensity and dietary protein level affect adipocyte cellularity and lipogenic capacity of muscle homogenates in growing pigs, without modification of the expression of sterol regulatory element binding protein. J Anim Sci 80: 3184-3193, 2002.

18. Hansen JB, Zhang H, Rasmussen TH, Petersen RK, Flindt EN, Kristiansen K. Peroxisome proliferator-activated receptor delta (PPARdelta)-mediated regulation of preadipocyte proliferation and gene expression is dependent on cAMP signaling. J Biol Chem 276: 3175-3182, 2001.

19. Hauser N, Mourot J, De Clercq L, Genart C, Remacle C. The cellularity of developing adipose tissues in Pietrain and Meishan pigs. Reprod Nutr Dev 37: 617-625, 1997.

20. Hood RL, Allen CE. Lipogenic enzyme activity in adipose tissue during the growth of swine with different propensities to fatten. J Nutr 103: 353-362, 1973.
21. Iannuccelli E, Woloszyn N, Arhainx J, Gellin J, Milan D. Gemma: a database to automate microsatellite genotyping. 25th Int Conf Anim Genet Tours France, 1996, p. 88.

22. Jackman MR, Willis WT. Characteristics of mitochondria isolated from type I. and type IIb skeletal muscle. Am J Physiol Cell Physiol 270: C673-C678, 1996.

23. Kim JY, Hickner RC, Cortright RL, Dohm GL, Houmard JA. Lipid oxidation is reduced in obese human skeletal muscle. Am J Physiol Endocrinol Metab 279: E1039-E1044, 2000.

24. Kim KS, Lee JJ, Shin HY, Choi BH, Lee CK, Kim JJ, Cho BW, Kim TH. Association of melanocortin 4 receptor (MC4R) and high mobility group AT-hook 1 (HMGA1) polymorphisms with pig growth and fat deposition traits. Anim Genet 37: 419-421, 2006.

25. Kim KS, Thomsen H, Bastiaansen J, Nguyen NT, Dekkers JC, Plastow GS, Rothschild MF. Investigation of obesity candidate genes on porcine fat deposition quantitative trait loci regions. Obes Res 12: 19811994, 2004.

26. Lavau M, Susini C, Knittle J, Blanchet-Hirst S, Greenwood MR. A reliable photomicrographic method to determining fat cell size and number: application to dietary obesity. Proc Soc Exp Biol Med 156: 251-256, 1977.

27. Lefaucheur L, Milan D, Ecolan P, Le Callennec C. Myosin heavy chain composition of different skeletal muscles in Large White and Meishan pigs. J Anim Sci 82: 1931-1941, 2004.

28. Le Roy P, Elsen JM, Boichard D, Mangin B, Bidanel JP, Goffinet B. An algorithm for QTL detection in mixture of full and half sib families. Proc 6th World Cong Genet Appl Livest Prod Armidale Australia XXVI, 1998, p. 257-260.

29. Louveau I, Gondret F. GH and insulin affect fatty acid synthase activity in isolated porcine adipocytes in culture without any modifications of sterol regulatory element binding protein-1 expression. J Endocrinol 181: 271-280, 2004.

30. Malek M, Dekkers JC, Lee HK, Baas TJ, Prusa K, Huff-Lonergan E, Rothschild MF. A molecular genome scan analysis to identify chromosomal regions influencing economic traits in the pig. II. Meat and muscle composition. Mamm Genome 12: 637-645, 2001.

31. Martin RJ, Gobble JL, Hartsock TH, Graves HB, Ziegler JH. Characterization of an obese syndrome in the pig. Proc Soc Exp Biol Med 143: 198-203, 1973.

32. Melillo RM, Pierantoni GM, Scala S, Battista S, Fedele M, Stella A, De Biasio MC, Chiappetta G, Fidanza V, Condorelli G, Santoro M, Croce CM, Viglietto G, Fusco A. Critical role of the HMGI(Y) proteins in adipocytic cell growth and differentiation. Mol Cell Biol 21: 2485-2495, 2001.

33. Milan D, Bidanel JP, Iannuccelli N, Riquet J, Amigues Y, Gruand J, Le Roy P, Renard C, Chevalet C. Detection of quantitative trait loci for carcass composition traits in pigs. Genet Sel Evol 34: 705-728, 2002.

34. Mourot J, Kouba M, Bonneau M. Comparative study of in vitro lipogenesis in various adipose tissues in the growing Meishan pig. Comparison with the Large White pig. Comp Biochem Physiol B 115: 383-388, 1996.

35. Munoz G, Ovilo C, Noguera JL, Sanchez A, Rodriguez C, Silio L. Assignment of the fatty acid synthase (FASN) gene to pig chromosome 12 by physical and linkage mapping. Anim Genet 34: 234-235, 2003.

36. Naaz A, Holsberger DR, Iwamoto GA, Nelson A, Kiyokawa H, Cooke PS. Loss of cyclin-dependent kinase inhibitors produces adipocyte hyperplasia and obesity. FASEB J 18: 1925-1927, 2004.

37. Nachlas MM, Tsou KC, De Souza E, Cheng CS, Seligman AM. Cytochemical demonstration of succinic dehydrogenase by the use of a new p-nitrophenyl substituted ditetrazole. J Histochem Cytochem 5: 420436, 1957.

38. Nunes M, Lahbib-Mansais Y, Geffrotin C, Yerle M, Vaiman M, Renard C. Swine cytosolic malic enzyme: cDNA cloning, sequencing, and localization. Mamm Genome 7: 815-821, 1996.

39. Rattink AP, De Koning DJ, Faivre M, Harlizius B, van Arendonk JA, Groenen MA. Fine mapping and imprinting analysis for fatness trait QTLs in pigs. Mamm Genome 11: 656-661, 2000.

40. Sanchez MP, Riquet J, Iannuccelli N, Gogue J, Billon Y, Demeure O, Caritez JC, Burgaud G, Feve K, Bonnet M, Pery C, Lagant H, Le Roy P, Bidanel JP, Milan D. Effects of quantitative trait loci on chromosomes $1,2,4$, and 7 on growth, carcass, and meat quality traits in backcross Meishan $\times$ Large White pigs. J Anim Sci 84: 526-537, 2006.

41. Scott RA, Cornelius SG, Mersmann HJ. Effects of age on lipogenesis and lipolysis in lean and obese swine. J Anim Sci 52: 505-511, 1981. 
42. Simoneau JA, Veerkamp JH, Turcotte LP, Kelley DE. Markers of capacity to utilize fatty acids in human skeletal muscle: relation to insulin resistance and obesity and effects of weight loss. FASEB J 13: 2051-2060, 1999.

43. Srere PA. Citrate synthase. Methods Enzymol 13: 3-11, 1969.

44. Tanaka M, Matsumoto T, Yanai S, Domukai M, Toki D, Hayashi T, Kiuchi S, Yasue H, Uenishi H, Kobayashi E, Awata T. Conservation of the syntenies between porcine chromosome 7 and human chromosomes 6 ,
14 and 15 demonstrated by radiation hybrid mapping and linkage analysis. Anim Genet 34: 255-263, 2003.

45. Unger RH. The physiology of cellular liporegulation. Annu Rev Physiol 65: 333-347, 2003.

46. Vassault A. Lactate dehydrogenase: UV-method with pyruvate and NADPH. In: Methods of Enzymatic Analysis (3rd ed.), edited by Bergemyer HU. Weinheim, Germany: Verlag Chemie, 1983, p. 118-126.

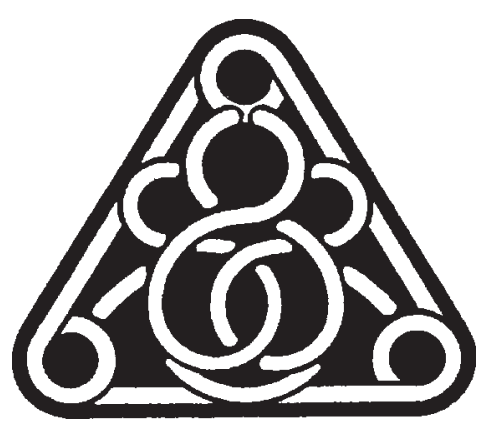

